\title{
Survey of Pasteuria, the parasitic bacterial group to plant parasitic nematodes in Turkey
}

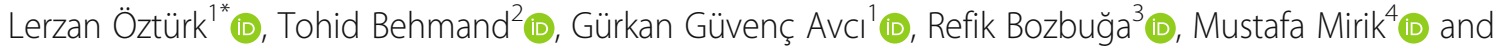 \\ Ibrahim Halil Elekcioğlu²(B)
}

\begin{abstract}
The present study was carried out in the agricultural areas of Northwestern Turkey with the purpose to assess the occurrence of Pasteuria spp. bacteria on plant-parasitic nematodes. The soil samples were collected from olive, cherry, peach, pear, almond, walnut, apple orchards, vineyards, vegetable, and sunflower fields, analyzed and the bacterium was detected on 30 nematode species belonging to 31 families. Nematode individuals from Rotylenchus, Helicotylenchus, Pratylenchus, Tylenchorrhynchus, and Geocenamus spp. were most frequently infected while the average height and width of the spore core and endospore ranged between 3.70-4.90 and 1.40-2.37 $\mu \mathrm{m}$, respectively. The results indicated that Helicotylenchus digonicus, Pratylenchus thornei, P. neglectus, Geocenamus brevidens, Tylenchhorhynchus cylindricus, Rotylenchus cypriensis, Meloidogyne javanica, and M.incognita individuals were the most parasitized by the bacterium.
\end{abstract}

Keywords: Soil bacteria, Occurrence, Pasteuria spp., Plant parasitic nematodes, Turkey

\section{Background}

The soil ecosystem consists of various micro and macroorganisms. Nematodes from the phylum Nematoda, which includes more than 20.000 identified species, are the most abundant group with 4.100 plant-parasitic species feeding on plant roots and causing yield loss up to 77\% (Abd-Elgawad and Askary 2015; Mitiku 2018). Yield reduction occurs as a result of root damage and secondary infections of disease agents that enter plant tissues from the nematode feeding sites (Brown 1997).

Nematodes living under the soil have mutualistic or parasitic interaction with many prokaryotic archaea and bacteria. The worldwide number of prokaryotic species was reported to be up to 10 million and only 4.000 were recorded in the soil. Among the bacterial prokaryotes, Pasteuria spp. from Pasteuriaceae are significant parasites of nematodes. Pasteuria spp. are gram (+)

\footnotetext{
* Correspondence: lerzanozturk@gmail.com

${ }^{1}$ Viticulture Research Institute, 59100, Süleymanpaşa, Tekirdag, Turkey Full list of author information is available at the end of the article
}

endospore-forming obligate bacteria, which are considered as one of the most effective agents with higher tolerance to unfavorable temperature and soil conditions (Walker and Wachtel 1988). The parasites have several beneficial features such as the ability to survive for up to 70 years in the soil without losing pathogenicity, forming endospore rapidly, attaching to host within $24 \mathrm{~h}$, being immune to different pesticides and being applicable with other natural enemies (Walker and Wachtel 1988; Bird et al. 2003; Chaudhary and Kaul 2011; and Stirling 2014). In addition, bacterium was able to suppress nematode populations under field conditions in a year of period (Tateishi and Sano 2001).

Pasteuria is the most specific obligate parasite that only adheres to the cuticle of nematodes without affecting other organisms. The bacterial endospores attached and sporulated inside the nematodes lead to loss of the reproduction ability by damaging the genital tract of females. The restrictive effect of bacterial infection on the movement of nematodes, results in a decrease of the 
number of specimens that reach the plant roots and cause damage (Kariuki and Dickson 2007).

Several species of bacteria are reported to infect all economically important nematode pests and multiply to a level that is adequate for population suppression. Throughout the world, 8 Pasteuria species including $P$. thornei, $P$. penetrans, $P$. nishizawae, $P$. usgae, $P$. ramosa, $P$. hartismeri, $P$. goettingianae, and $P$. aldrichii were identified on 323 nematode species from 116 genera in 80 countries (Giblin-Davis et al. 2003; Cho et al. 2005; Bishop et al. 2007; Giblin-Davis et al. 2011; and Stirling 2014). The only report on the presence of nematophagous bacteria in Turkey was in the East Mediterranean Region (Elekcioğlu 1995).

The present study was carried out based on data on host association, distribution, and impact of climate and soil type in Northwestern Turkey. Also, the incidence map was created and host status by genus and species level were included.

\section{Materials and methods}

\section{Survey and soil sample collection}

An extensive nematode survey was carried out at Edirne (Keşan, Meriç, İpsala, Enez, Uzunköprü districts), Kırklareli (Merkez district), and Tekirdağ (Malkara, Süleymanpaşa, Şarköy, Hayrabolu districts) provinces of the Northwestern Marmara Region in Turkey, in order to collect soil samples and evaluate the presence of bacterial infected nematode species. Research was conducted between 2017-2019 years and each year field surveys started in April and lasted in late October. Sampled fields were randomly selected grapevine (Vitis vinifera L./143 vineyards), apple (Malus domestica Borkh/34 orchards), pear (Pyrus communis L./40 orchards), peach (Prunus persica (L.) Batsch/33 orchards), almond (Prunus amygdalus L./46 orchards), walnut (Juglans regia L./
51 orchards), cherry (Prunus avium L./66 orchards), fig (Ficus carica L./30 orchards), olive (Olea europaea L./26 orchards), sunflower (Helianthus annuus L./36 fields), wheat (Triticum aestivum L./11 fields), and vegetable fields (17 fields). A total of 5 subsamples with an amount of $1 \mathrm{~kg}$ were collected from each field at $10-40 \mathrm{~cm}$ soil depth.

\section{Bacteria and nematode extraction, species identification}

The nematodes were extracted from $200 \mathrm{~g}$ sub-soil by sieving with 60,400 mesh sieves, followed by centrifugal flotation. The isolated nematodes were heat-killed at $55^{\circ} \mathrm{C}$ for $1 \mathrm{~min}$ and fixed in a double strengthen formalin-triethanolamine solution (Seinhorst 1959; Jenkins 1964; Brown and Boag 1988). Prior to analysis, all samples were separated based on their vegetation type and district in order to determine the distribution and nematode associated to each host plant. Right after individuals attached with Pasteuria spp. were hand-picked from extracted nematode suspensions at $\times 100$ magnification and mounted on slides by the wax-ring method described by (Hooper 1986). Prepared slides were examined with a Leica DM1000 microscope, the morphometric of nematodes and the endospore size of bacteria were measured, using the Leica Application Suite software. The images of infected individuals were taken by Leica ICC50 W camera. Colony shape and sporangia size of bacteria were used to confirm Pasteuria, while nematode identifications by genus and species level were performed with the published keys of Geraert and Raski (1987), Loof and Luc (1990), Brzeski (1991), Castillo and Vovlas (2005), and Handoo et al. (2007).

\section{Results and discussions}

Among 516 soil samples collected for the study, the occurrence rate of nematodes attached by Pasteuria was

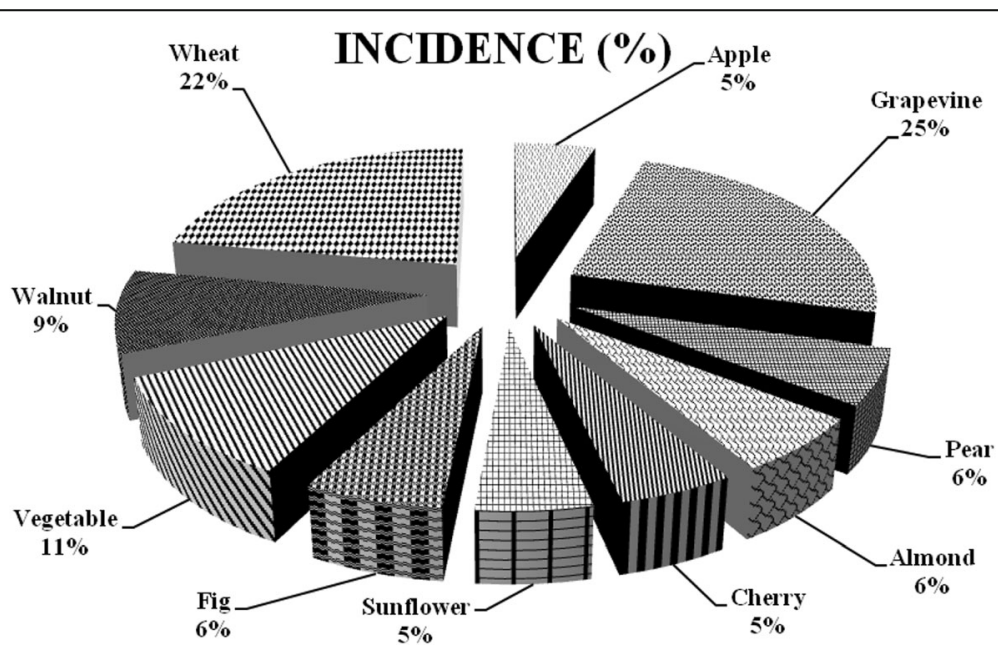

Fig. 1 Occurrence percentage of Pasteuria spp. in different vegetations 
Table 1 Host nematode genera and occurance of Pasteuria in Edirne, Kırklareli, Çanakkale and Tekirdağ provinces

\begin{tabular}{|l|l|c|c|c|c|c|c|}
\hline \multirow{2}{*}{\multicolumn{2}{|c|}{ GENERA }} & \multicolumn{2}{c|}{ Edirne } & \multicolumn{2}{c|}{ Kurklareli } & \multicolumn{2}{c|}{ Tekirdağ } \\
\cline { 2 - 8 } & A & B & A & B & A & B \\
\hline 1 & Aphelenchus & + & + & + & + & + & + \\
\hline 2 & Aphelenchoides & + & - & + & + & + & - \\
\hline 3 & Basiria & + & - & - & - & + & - \\
\hline 4 & Boleodorus & + & - & + & - & + & + \\
\hline 5 & Coslenchus & + & - & + & - & + & - \\
\hline 6 & Criconema & + & - & + & - & + & + \\
\hline 7 & Ditylenchus & + & - & + & - & + & + \\
\hline 8 & Dorylaimus & + & + & + & - & + & - \\
\hline 9 & Filenchus & + & - & + & - & + & + \\
\hline 10 & Geocenamus & + & + & + & + & + & + \\
\hline 11 & Gracillacus & - & - & - & - & + & - \\
\hline 12 & Helicotylenchus & + & - & + & + & + & + \\
\hline 13 & Heterodera & + & - & + & - & + & - \\
\hline 14 & Meloidogyne & + & - & - & - & + & + \\
\hline 15 & Mesocriconema & + & - & + & - & + & + \\
\hline 16 & Paratylenchus & + & - & - & - & + & - \\
\hline 17 & Paratrophurus & - & - & - & - & + & + \\
\hline 18 & Pratylenchus & + & - & + & - & + & + \\
\hline 19 & Pratylenchoides & + & - & - & - & + & - \\
\hline 20 & Psilenchus & + & - & - & - & + & - \\
\hline 21 & Radophulus & - & - & - & - & + & - \\
\hline 23 & Rotylenchus & + & + & + & - & + & + \\
\hline 24 & Rotylenchulus & - & - & - & - & + & + \\
\hline 25 & Scutylenchus & - & - & + & - & - & - \\
\hline 26 & Trichodorus & + & - & + & - & - & - \\
\hline 27 & Trophurus & - & - & - & - & + & - \\
\hline 28 & Tylenchorrhynchus & + & + & + & + & + & + \\
\hline 29 & Tylenchus & + & - & - & - & + & - \\
\hline 30 & Xiphinema & - & - & - & - & + & - \\
\hline 31 & Zygotylenchus & + & + & - & + & + \\
\hline
\end{tabular}

calculated as $19.3 \%$ (100 samples). Most of the Pasteuria positive samples were collected from the coastal Şarköy and Süleymanpaşa districts of Tekirdağ and Merkez district of Kırklareli. The more frequent incidence of bacteria is considered as the result of more moderate soil temperatures in Tekirdağ and sandiest soil conditions in
Kurklareli. In addition, a positive correlation between nematode population increase and bacterium infection was observed in all locations. Since there are many published research results related to the increase of nematode species and populations under temperate and sandy soil conditions, the highest parasitism is considered to 
be the result of higher nematode abundance. The bacterium was found only in one or two samples in Uzunköprü, Meriç, İpsala, and Keşan districts.

There were significant variations of infection in the point of vegetation type. Most cases were observed in vineyards (57 vineyards) in both provinces. The other crop plants in infected areas were sunflower ( 7 fields), wheat (4 fields), vegetable fields (3 fields), walnut (8 orchards), fig (3 orchards), cherry ( 6 orchards), almond (5 orchards), apple (3 orchards), and pear ( 4 orchards) (Fig. 1). The main reason for this variation was the soil type. The vineyards in the region were mostly established in soils with lower clay and higher sand content, while in many studies Pasteuria was reported to transport more easily in these conditions (Dabiré and Mateille 2003). The other reason for the infection was host plant susceptibility. The total number of healthy and infected nematodes varied between host crop plants, while the highest number of nematodes was observed in vineyard soils. The olive samples, collected only from Şarköy district and despite warmer soil temperatures and sandy soil type the bacterium, was not detected in any of the samples. Different sized cup-shaped bacterial endospores were observed adhering to the cuticle of nematode species from 32 families (Table 1).

The bacterial isolates were observed on 28 plant-parasitic nematode species listed in Table 2 . In addition, the bacterium was found on Criconema and Dorylaimus juveniles. Based on feeding habitat, 4 species were classified as fungivorous nematode, 5 species as endoparasite, 1 specie as semi-endoparasite and the rest as ectoparasite. The

Table 2 The list of plant parasitic nematodes, the number of soil samples infected, attachement rate, nematode stage in Northwestern Marmara Region

\begin{tabular}{|c|c|c|c|c|}
\hline Nematode species & Samples infected & Endospore numbers & Attachment & Nematode stage \\
\hline Aphelenchus avenae & 4,0 & 2,50 & Cuticle & Female \\
\hline Aphelenchoides confusus & 1,0 & 1,0 & Cuticle & Female \\
\hline Boleodorus thylactus & 1,0 & 2,0 & Cuticle, within the body & Juvenile \\
\hline Criconema sp. & 1,0 & 5,0 & Cuticle & Juvenile \\
\hline Dorylaimus sp. & 7,0 & $>50$ & Cuticle, within the body & Juvenile \\
\hline Ditylenchus dipsaci & 2,0 & $2->50$ & Cuticle, within the body & Female, juvenile \\
\hline Filenchus thornei & 5,0 & 2,0 & Cuticle & Female \\
\hline Filenchus sheri & 1,0 & 1,0 & Cuticle & Female \\
\hline Geocenamus brevidens & 6,0 & 3,0 & Cuticle & Female, male \\
\hline Geocenamus microdorus & 5,0 & 3,0 & Cuticle & Female \\
\hline Helicotylenchus canadensis & 4,0 & 2,50 & Cuticle & Female \\
\hline Helicotylenchus varicaudatus & 2,0 & 3,50 & Cuticle & Female \\
\hline Helicotylenchus digonicus & 4,0 & 9,0 & Cuticle & Female \\
\hline Helicotylenchus multicinctus & 2,0 & 2,0 & Cuticle & Female \\
\hline Helicotylenchus platyurus & 2,0 & 1,50 & Cuticle & Female \\
\hline Helicotylenchus dihystera & 3,0 & 3,0 & Cuticle & Female \\
\hline Mesocriconema xenoplax & 2,0 & 3,0 & Cuticle & Female \\
\hline Paratrophurus loofi & 1,0 & 3,0 & Cuticle & Female \\
\hline Meloidogyne javanica & 1.0 & 10 & Cuticle & Juvenile \\
\hline Meloidogyne incognita & 1.0 & 7.0 & Cuticle & Juvenile \\
\hline Pratylenchus penetrans & 1,0 & 2,30 & Cuticle & Female \\
\hline Pratylenchus neglectus & 3,0 & 3,0 & Cuticle, & Female \\
\hline Pratylenchus thornei & 4,0 & 3,20 to $>50$ & Cuticle, within the body & Female, juvenile \\
\hline Rotylenchulus anamictus & 2,0 & $>50$ & Cuticle, within the body & Female \\
\hline Rotylenchus cypriensis & 14,0 & 6,71 & Cuticle & Female \\
\hline Rotylenchus glabratus & 1,0 & 1,0 & Cuticle & Female \\
\hline Rotylenchus brevicaudatus & 1,0 & 1,0 & Cuticle & Female \\
\hline Tylenchorrhynchus cylindricus & 7,0 & 10,70 & Cuticle & Female, male \\
\hline Tylenchorrhynchus nudus & 1,0 & 2,0 & Cuticle & Female \\
\hline Xiphinema pachtaicum & 2,0 & 1,50 & Cuticle & Juvenile \\
\hline
\end{tabular}



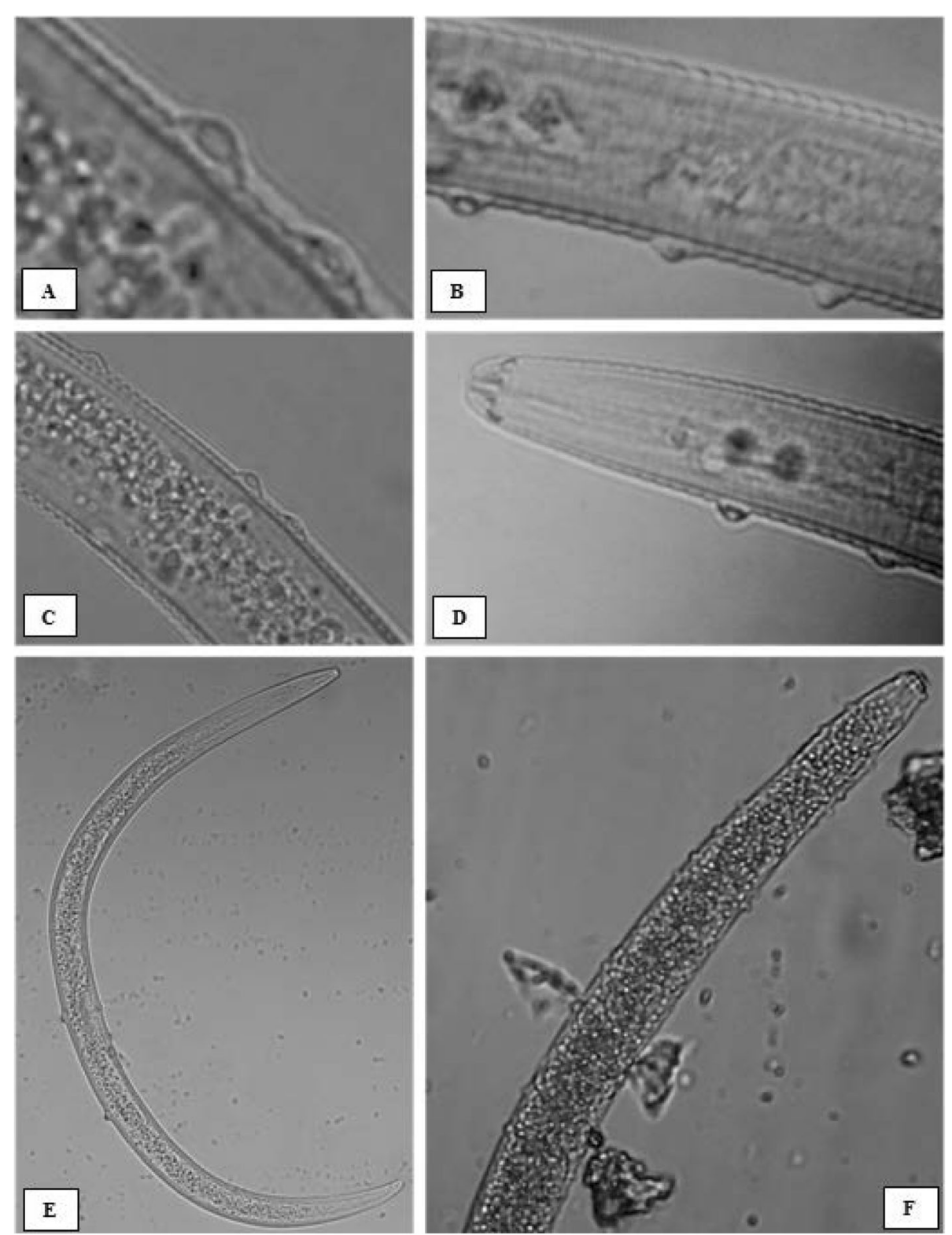

Fig. 2 a Pasteuria endospore attached to nematode cuticle. b, c, d Endospore on Helicotylenchus digonicus. e Endospore on Geocenamus brevidens. f Heavy infection on Pratyenchus thornei

individuals parasitized by bacteria and endospores were mostly detected in the outer cuticle of the head, middle body, and tail region of mature females (Fig. 2). Except for individuals from Filenchus, Aphelenchus, Aphelencoides, Boleodorus, and Criconema genera, which were mostly infected only from the head, most of the specimens from Helicotylenchus, Tylenchorrhynchus, Meloidogyne, Pratylenchus, and Geocenamus were found attached both from head, mid body, and tail region. Furthermore, the bacterium was observed in the head and tail region of two Xiphinema pachtaicum and Mesocriconema xenoplax samples (Table 3).
The impact of the degree of parasitism on nematode movement was observed only on $P$. thornei, $T$. cylindricus, $D$. dipsaci, G. brevidens, and R. cyprinesis. The number of endospores adhering to the cuticle of specimens ranged from 1 to more than 50. Lesion nematode $P$. thornei, onion bulb nematode $D$. dipsaci, omnivore Dorylaimus sp., and the reniiform nematode $R$. anamictus had mature endospores filled inside nematode body and thus dead individuals were collected from 5 vineyards. The rate of totally filled specimens was $14.7 \%$. In most locations, 17 species were found attached with at least 3 endospores per nematode, while A. confusus, B. thylactus, F. thornei, F. sheri, $H$. 
Table 3 Endospore measurements of different Pasteuria isolates

\begin{tabular}{lll}
\hline Nematode species & $\begin{array}{l}\text { Endospore dimeter } \\
(\mu \mathrm{m})\end{array}$ & $\begin{array}{l}\text { Endospore heigh } \\
(\mu \mathrm{m})\end{array}$ \\
\hline Aphelenchus avenae & $4,0 \pm 0,11$ & $1,40 \pm 0,11$ \\
Ditylenchus dipsaci & $4,0 \pm 0,08$ & $1,73 \pm 0,12$ \\
Filenchus thornei & $3,70 \pm 0,17$ & $1,82 \pm 0,25$ \\
Geocenamus brevidens & $4,90 \pm 0,25$ & $1,96 \pm 0,04$ \\
Helictylenchus & $4,17 \pm 0,17$ & $2,0 \pm 0.15$ \\
varicaudatus & & $2,15 \pm 0,15$ \\
Mesocriconema xenoplax & $4,05 \pm 0,05$ & $2,37 \pm 0,22$ \\
Rotylenchus cypriensis & $4,22 \pm 0,17$ & $2,2 \pm 0,15$ \\
Pratylenchus thornei & $3,81 \pm 0,12$ & $2,10-2,50$ \\
$\begin{array}{l}\text { Tylenchhorhynchus } \\
\text { cylindricus }\end{array}$ & $7,0-8,40$ & $1,92 \pm 0,07$ \\
Xiphinema pachtaicum & $4,30 \pm 0,10$ &
\end{tabular}

multicinctus, $H$. platyurus, $R$. brevicaudatus, R. glabratus, T. nudus, and $X$. pachtaicum had only one or two endospore. The endospore and central core diameter of specimens were quite similar and in most cases the mean average ranged between 3.70-4.90 and 1.40-2.37, respectively. Depending on higher morphometrics (7.0-8.40) of $T$. cylindricus, it was believed that it may belong to different Pasteuria species.

R. cypriensis $(11.4 \%)$ was the leading nematode in the point of parasitism frequency, followed by T. cylindricus (7.1\%). Isolated from 10 vineyards and 4 other vegetation, the nematode was attached by at least 6 bacterial spores that were only observed on the upper layer of cuticle.

According to the survey collected data, the bacterium gave promising results as potential biological control candidate of $D$. dipsaci, $P$. thornei, T. cylindricus, $R$. cypriensis, $R$. anamictus, and Criconema sp. D. dipsaci is known to attack more than 450 different plant species and is reported to cause $50-60 \%$ yield loss in garlic and onion as P.thornei (Sturhan and Brzeski 1991). Meanwhile, M. javanica and $M$. incognita are two endoparasitic nematode that can cause $25-100 \%$ yield loss (Wesemael et al. 2011). The other species may accidentally be infected since the bacterium had a lower number of endospores on nematodes.

The previous study carried out to evaluate the Pasteuria species in the agricultural areas in Turkey was by Elekcioğlu (1995) in Southeastern Mediterranean region, and the bacteria were identified on nematodes from 10 genera. The identified species were Aphelenchus avenae, Meloidogyne arenaria, M. incognita, M. javanica, Geocenamus brevidens, Pratylenchus penetrans, P. thornei, Rotylenchulus macrosomus, $R$. parvus, Tylenchulus semipenetrans. The results recorded in this study: A.confusus, F. sheri, Dorylaimus sp., D. dipsaci, $H$. dihystera, $H$. digonicus, $H$. varicaudatus, $H$. platyurus, $H$. canadensis, $M$. microdorus, M. xenoplax, $R$. brevicaudatus, R. cypriensis,
R. glabratus, R. anamictus, P. loofi, T. cylindricus, and T. nudus constitute new hosts for the country.

\section{Conclusion}

The Pasteuria spp. bacterial isolates were detected in 30 nematode species isolated from soil samples collected from the agricultural areas of Edirne, Kurklareli, and Tekirdağ provinces in Turkey. Pasteuria isolates have been recommended as the most beneficial bacteria with many advantageous features such as tolerance to higher temperatures.

\section{Abbreviations \\ spp: several species}

\section{Acknowledgements}

We are thankful to the reviewers for their useful comments on the revision of the manuscript. We also are thankful to Assoc. Prof. Pedru Golman for the proofreading of the manuscript.

\section{Authors' contributions}

All authors work in the study and prepare the manuscript together. All authors approved the final manuscript. The identification of bacterium was carried out by MM. The nematodes were identified by LÖ and IHE.

Funding

Not funded

\section{Availability of data and materials}

The available data is included in present manuscript. Results of this study can be used as a reference by other researchers.

Ethics approval and consent to participate

Not applicable. Ethical approval is not required for this study.

Consent for publication

Not applicable

\section{Competing interests}

The authors declare that they have no competing interests.

\section{Author details}

${ }^{1}$ Viticulture Research Institute, 59100, Süleymanpaşa, Tekirdag, Turkey. ${ }^{2}$ Department of Plant Protection, Faculty of Agriculture, Çukurova University, 01360, Balcalı, Adana, Turkey. ${ }^{3}$ Biological Control Central Research Institute, 01360 Adana, Turkey. ${ }^{4}$ Department of Plant Protection, Faculty of Agriculture, Namik Kemal University, 59100, Süleymanpaşa, Tekirdağ, Turkey.

Received: 8 January 2020 Accepted: 16 April 2020

Published online: 28 May 2020

\section{References}

Abd-Elgawad MMM, Askary TH (2015) Impact of phytonematodes on agriculture economy. In: Askary TH, Martinelli PRP (eds) Biocontrol Agents of Phytonematodes. CAB International, UK, Wallingford, pp 3-49

Bird DM, Opperman CH, Davies KG (2003) Interactions between bacteria and plant-parasitic nematodes. Int J Parasitol 33:1269-1276

Bishop AH, Gowen SR, Pembroke B, Trotter JR (2007) Morphological and molecular characteristics of a new species of Pasteuria parasitic on Meloidogyne ardenensis. J Inverteb Pathol 96:28-33

Brown DJF (1997) The nematode transmitted viruses. Pp.273-311 in M.S. N. de A. Santos, I.M. O. Abrantes, D.J.F. Brown and R. M. Lemos (eds) An introduction to virus vector nematodes and their associated viruses. IAV, Departamento de Zoologia Universidade de Coimbra, Portugal.

Brown DJF, Boag B (1988) An examination of methods used to extract virusvector nematodes (Nematoda: Longidoridae and Trichodoridae) from soil samples. Nematologia Mediterranea 16:93-99

Brzeski MW (1991) Review of the genus Ditylenchus Filipjev, 1936 (Nematoda: Anguinidae). Revue Nematol 14:9-59 
Castillo P, Vovlas N (2005) Bionomics and identification of Rotylenchus species. Nematol Monographs Perspect Brill Acad Pub 3:316-148

Chaudhary KK, Kaul RK (2011) Compatibility of Pasteuria penetrans with fungal parasite Paecilomyces lilacinus against root knot nematode on Chilli (Capsicum annuum L.). South Asian J Exp Biol 1:36-42

Cho MR, Dickson DW, Hewlett TE (2005) Comparison of inoculation methods, Meloidogyne spp. and different host plants for production of Pasteuria penetrans. Korean J Appl Entomol 8(3):297-300

Dabiré KR, Mateille T (2003) Soil texture and irrigation influence the transport and the development of Pasteuria penetrans, a bacterial parasite of root-knot nematodes. Soil Biol Biochem 36:343-351

Elekcioğlu IH (1995) Occurrence of Pasteuria bacteria as parasites of plantparasitic nematodes in the East Mediterranean Region of Turkey. Nematologia Mediterranea 23:213-215

Geraert E, Raski DJ (1987) A reappraisal of Tylenchina (Nemata). Nematology 10(2):143-161

Giblin-Davis RM, Nong G, Preston JF, Williams DS, Center BJ, Brito JA (2011) Candidatus Pasteuria aldrichii', an obligate endoparasite of the bacterivorous nematode Bursilla. Int J Syst Evol Microbiol 61:2073-2080

Giblin-Davis RM, Williams DS, Bekal S, Dickson DW, Brito JA, Becker JO, Preston JF (2003) 'Candidatus Pasteuria usgae' sp. nov., an obligate endoparasite of the phytoparasitic nematode Belonolaimus longicaudatus. Int J Syst Evol Microbiol 53:197-200

Handoo ZA, Khan A, Islam S (2007) A key and diagnostic compendium to the species of the genus Merlinius Siddiqi, 1970 (Nematoda: Tylenchida) with description of Merlinius khuzdarensis n. sp. associated with date palm. Nematology 9:251-260. https://doi.org/10.1163/156854107780739045

Hooper DJ (1986) Extraction of free-living stages of soil. In: Southey JF (ed) Laboratory methods for work with plant and soil nematodes. Ministry of Agriculture Fisheries and Food, Reference Book 402, UK, pp 5-30

Jenkins WR (1964) A rapid centrifugal flotation technique for separating nematodes from soil. Plant Dis Rep 48:692

Kariuki GM, Dickson DW (2007) Effects of two summer crops and population densities of Meloidogyne arenaria race 1 on amplification of Pasteuria penetrans. J Nematol 39:81-85

Loof PAA, LuC M (1990) A revised polytomous key for the identification of species of the genus Xiphinema Cobb,1913 (Nematoda: Longidoridae) with exclusion of the $X$. americanum-group. Syst Parasitol 16:36-66

Mitiku M (2018) Plant-parasitic nematodes and their management: a review. Agric Res Technol 16. https://doi.org/10.19080/ARTOAJ.2018.16.55580

Seinhorst JW (1959) A rapid method for the transfer of nematodes from fixative to anhydrous glycerin. Nematologica 4:67-69

Stirling GR (2014) Biological control of plant-parasitic nematodes, 2nd edn. CAB International, Wallingford

Sturhan D, Brzeski MW (1991) Stem and bulb nematodes, Ditylenchus spp. In: Nickle WR (ed) Manual of Agricultural Nematology. Marcel Dekker, New York, pp 423-464

Tateishi Y, Sano Z (2001) Pasteuria penetrans for controlling Meloidogyne incognita on sweet potato cultivars with different susceptibility to the root-knot nematode. II. Nematode suppressive effects during the 7th to the 9th cropping seasons. Kyushu Plant Protect Res 47:118-122. https://doi.org/10.4241/kyubyochu.47.118

Walker GE, Wachtel MF (1988) The influence of soil solarization and non-fumigant nematicides on infection of Meloidogyne javanica by Pasteuria penetrans. Nematologica 34:477-483

Wesemael WML, Viaene N, Moens M (2011) Root-knot nematodes (Meloidogyne spp.) in Europe. Nematology 13:3-16

\section{Publisher's Note}

Springer Nature remains neutral with regard to jurisdictional claims in published maps and institutional affiliations.

\section{Submit your manuscript to a SpringerOpen ${ }^{\circ}$ journal and benefit from:}

- Convenient online submission

- Rigorous peer review

- Open access: articles freely available online

- High visibility within the field

- Retaining the copyright to your article

Submit your next manuscript at $\boldsymbol{\nabla}$ springeropen.com 